\title{
Ozone Damages to Italian Crops: Environmental Constraints
}

\author{
Massimo Fagnano*, Albino Maggio \\ Dipartimento di Ingegneria Agraria e Agronomia del Territorio, Università di Napoli Federico II \\ Via Università 100, 890055 Portici (NA), Italy
}

Received: 7 January 2008. Accepted 28 January 2008.

\begin{abstract}
The main environmental features of Italian cropping systems are described with particular emphasis on their effects on crop responses to ozone pollution.

High ozone levels have been recorded all over Italy and daily patterns show, at nighttimes, strong decreases in plain areas, while ozone levels remain high in hilly areas. In the latter sites, therefore, the contribution of nocturnal stomatal conductance $\left(\mathrm{g}_{\text {sto }}\right)$ to ozone uptake should be further studied. It is well known that summer drought and soil salinity reduce the soil water potential, thus causing $g_{\text {sto }}$ to decrease. These are likely to be the most important factors reducing crop gas-exchange and yield under environmental conditions occurring in Italy. However, the stressinduced reduction of $g_{\text {sto }}$ also restricts ozone uptake and, consequently, its potential damage. In Southern Italy, gasexchange limitations have been also measured in irrigated crops between two successive irrigations. Finally, the effect of water stagnation, which often occurs in clay soils of southern Italy, should be not underestimated. In these soils, in fact, root anoxia will cause stomatal closure and, consequently, will also interfere with ozone uptake and damage.
\end{abstract}

Key-words: Italian environment, abiotic stresses, ozone, drought, salinity.

\section{Introduction}

Atmospheric pollution can cause severe losses of crop yields, and ozone is considered the most important component of polluted air in Mediterranean environments (Lorenzini, 1999). Ozone is considered the most important pollutant of rural areas where, unlike the cities, there are few other pollutants (i.e. NO) that react with ozone to reduce its concentration (Hayes et al., 2007). Prediction analyses also estimate that, during this Century, a severe increase of ozone levels in central and southern Europe will occur (Sitch et al., 2007).

This pollutant is well known as the most harmful for vegetation (Heck et al., 1982), but only in the last decade its effects on crops have become a major concern in Europe (Fuhrer et al., 1997) and in Italy (Nali et al., 2002; Fagnano et al., 2008).
Since ozone penetration into plant tissues occurs mainly through stomata, all the factors that reduce stomatal conductance could also reduce ozone uptake by leaves and the consequent damages to crops (Guderian, 1985; Darrall, 1989; Iqbal et al., 1996).

The Italian (16/5/96 DM) and European (directive 2002/3/CE) legislations refer to a concentration-based critical level for calculating the thresholds for ozone damages to vegetation. However, previous studies carried out in Italy (Ferretti et al., 2007) reported that ozone concentration was poorly correlated with yield loss, even though the former was often much higher than the recommended threshold. Therefore it is necessary to revise the European legislation by adopting flux-based models, able to estimate the reduction of plant stomatal conductance, and ozone uptake, caused by environmental constraints.

\footnotetext{
* Corresponding Author: Tel.: +39 081 2539129. E-mail address: fagnano@unina.it
} 
In this context, the aim of this paper is to present the environmental conditions of Italian cropping systems, with particular attention to those features that can modify crop ozone uptake.

\section{Ozone pollution}

In Italy, ozone levels are particularly high (Tab. 1) and AOT40 (the hourly concentrations exceeding the $40 \mathrm{ppb}$ threshold cumulated over a 90 days period) reaches values much higher than the $3000 \mathrm{ppb}$ h critical threshold, without differences between northern and southern locations (Manes et al., 2002).

Daily patterns of ozone are quite different depending on site elevation. In plain areas, ozone concentration peaks are recorded in the afternoon and the decreasing phase occurs during the evening-night hours to reach the minimum values at dawn (Fig. 1). Such trend correlates to air temperature more than to solar radiation (Fagnano, 1995).

On the contrary, on hills and mountains the decreasing phases of ozone concentration is strongly reduced, thus determining high ozone values during nighttimes and a small amplitude of the daily cycles (Fig. 2). This feature has been detected both in hilly areas $>700 \mathrm{~m}$ a.s.l. (Forlani et al., 2005) and in mountain areas (Vecchi and Valli, 1999).

The night ozone level is often overlooked by current ozone uptake models, although in the elevated sites of Italy it may significantly con-

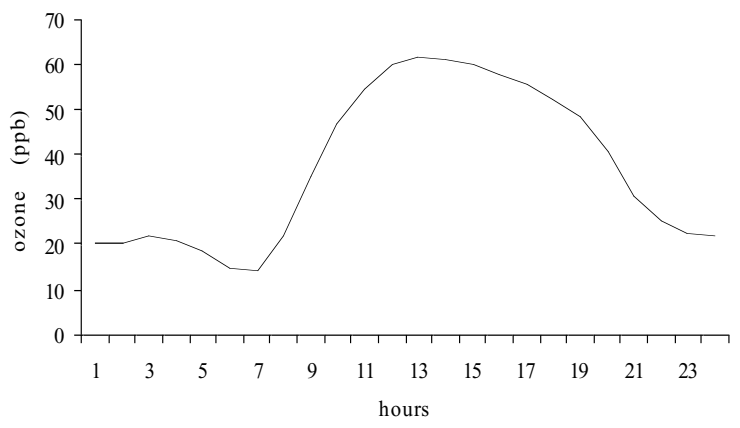

Figure 1. Daily trend of ozone during summer (June-August): mean values 2000-2004 recorded in Portici, NA, 30 m a.s.l.

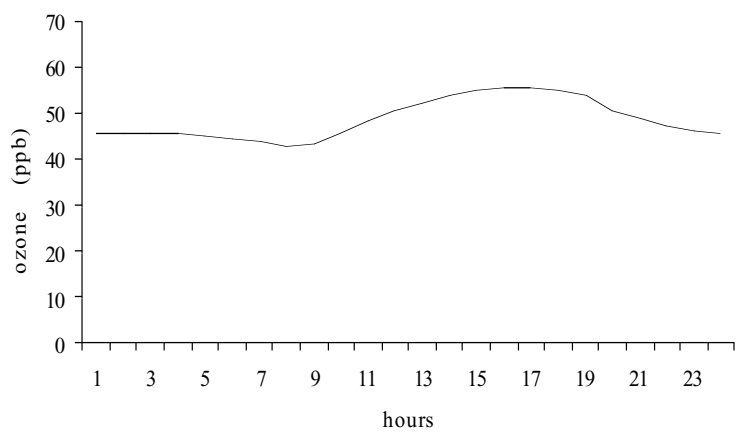

Figure 2. Daily trend of ozone during summer (June-August): mean values 2000-2002 recorded in S. Angelo dei Lombardi, AV, $700 \mathrm{~m}$ a.s.l.

tribute to reach a damage concentration threshold.

The relationship between ozone pollution, stomatal conductance and ozone uptake by plants, however, is not unequivocal Schenone et

Table 1. Ozone levels in different Italian locations.

\begin{tabular}{lcccccccl}
\hline Site & Coordinates & Elevation & Year & $\mathrm{O}_{3} \mathrm{max}$ & AOT $_{40}$ & Period & Days & References \\
\hline Isola serafini & $45^{\circ} 05^{\prime} \mathrm{N} ; 9^{\circ} 56^{\prime} \mathrm{E}$ & 40 & 2000 & 68.8 & 20.0 & $17 / 5-6 / 9$ & 112 & Manes et al., 2002 \\
Roma & $41^{\circ} 54^{\prime} \mathrm{N} ; 12^{\circ} 31^{\prime} \mathrm{E}$ & 20 & 2000 & 60.3 & 13.5 & $19 / 5-8 / 9$ & 112 & Manes et al., 2002 \\
Portici & $40^{\circ} 49^{\prime} \mathrm{N} ; 14^{\circ} 20^{\prime} \mathrm{E}$ & 30 & 2000 & 76.8 & 22.9 & $19 / 5-8 / 9$ & 112 & Manes et al., 2002 \\
S.Angelo dei L. & $40^{\circ} 55^{\prime} \mathrm{N} ; 15^{\circ} 10^{\prime} \mathrm{E}$ & 700 & 2000 & 67.3 & 23.9 & $15 / 5-4 / 9$ & 112 & Manes et al., 2002 \\
Bellizzi & $40^{\circ} 37^{\prime} \mathrm{N} ; 4^{\circ} 56^{\prime} \mathrm{E}$ & 30 & 2000 & 56.8 & 7.5 & $12 / 5-1 / 9$ & 112 & Manes et al., 2002 \\
Portici & $40^{\circ} 49^{\prime} \mathrm{N} ; 14^{\circ} 20^{\prime} \mathrm{E}$ & 30 & 2001 & 64.2 & 14.8 & $25 / 6-15 / 10$ & 112 & Forlani et al., 2005 \\
S.Angelo dei L. & $40^{\circ} 55^{\prime} \mathrm{N} ; 15^{\circ} 10^{\prime} \mathrm{E}$ & 700 & 2001 & 53.7 & 8.6 & $30 / 6-14 / 10$ & 106 & Forlani et al., 2005 \\
Bellizzi & $40^{\circ} 37^{\prime} \mathrm{N} ; 14^{\circ} 56^{\prime} \mathrm{E}$ & 30 & 2001 & 55.8 & 12.5 & $20 / 6-17 / 10$ & 119 & Forlani et al., 2005 \\
Portici & $40^{\circ} 49^{\prime} \mathrm{N} ; 14^{\circ} 20^{\prime} \mathrm{E}$ & 30 & 2002 & 52.1 & 7.4 & $25 / 6-15 / 10$ & 112 & Forlani et al., 2005 \\
S.Angelo dei L. & $40^{\circ} 55^{\prime} \mathrm{N} ; 15^{\circ} 10^{\prime} \mathrm{E}$ & 700 & 2002 & 49.4 & 6.6 & $27 / 6-16 / 10$ & 111 & Forlani et al., 2005 \\
Bellizzi & $40^{\circ} 37^{\prime} \mathrm{N} ; 4^{\circ} 56^{\prime} \mathrm{E}$ & 30 & 2002 & 52.7 & 4.3 & $20 / 6-17 / 10$ & 119 & Forlani et al., 2005 \\
Portici & $40^{\circ} 49^{\prime} \mathrm{N} ; 14^{\circ} 20^{\prime} \mathrm{E}$ & 30 & 2003 & 67.4 & 12.0 & $10 / 5-25 / 7$ & 57 & unpublished data \\
Portici & $40^{\circ} 49^{\prime} \mathrm{N} ; 4^{\circ} 20^{\prime} \mathrm{E}$ & 30 & 2004 & 61.6 & 10.0 & $10 / 5-25 / 7$ & 57 & Merola and Fagnano, 2006 \\
Bellizzi & $40^{\circ} 37^{\prime} \mathrm{N} ; 14^{\circ} 56^{\prime} \mathrm{E}$ & 30 & 2005 & 62.0 & 14.5 & $20 / 6-17 / 9$ & 89 & Fagnano et al., 2007 \\
Bellizzi & $40^{\circ} 37^{\prime} \mathrm{N} ; 14^{\circ} 56^{\prime} \mathrm{E}$ & 30 & 2006 & 59.2 & 10.1 & $4 / 5-2 / 8$ & 90 & Fagnano et al., 2007 \\
\hline
\end{tabular}




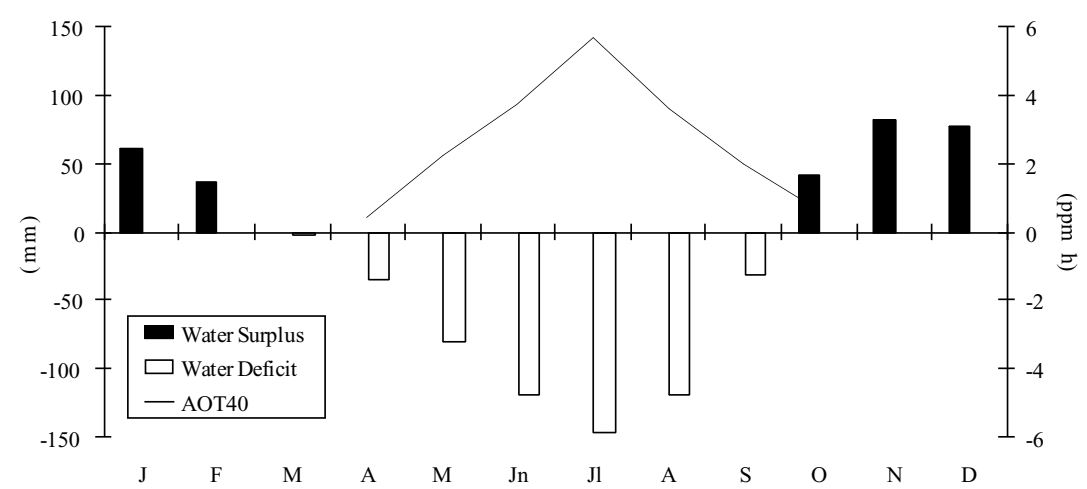

Figure 3. Monthly values of water balance (1920-1986) and AOT40 (1996-2003) in Naples. al., 1994). High $\mathrm{O}_{3}$ levels during daytime generally causes a reduction in stomatal conductance (Fagnano and Merola, 2007) as demonstrated by the significant correlation $\left(\mathrm{R}^{2}=0.67\right)$ between AOT40 and $\mathrm{g}_{\text {sto }}$ reduction (Bou Jaoudé et al., 2008a).

Nevertheless, high ozone levels may also lead to a slow stomatal response to light and, consequently, to an incomplete stomatal closure during nighttimes, which may increase $\mathrm{O}_{3}$ fluxes into the plant (Paoletti, 2005; Grulke et al., 2007). In addition, it should also be considered that the detoxification capacity of plants is less efficient during the night (Musselman and Minnick, 2000).

\section{Climatic conditions}

Among the other environmental factors that can modify plant responses to ozone, soil water deficit is the most common all over Italy.

Based on the data of Italian meteorological stations (2000-2004), a strong year variability can be noted (Tab. 2). The mean air temperature ranges from 12.0 to $22.3^{\circ} \mathrm{C}$, the potential evapotranspiration (Hargreaves et al., 1985) ranges from 841 to $1047 \mathrm{~mm}$ per year and total rainfall ranges from $575 \mathrm{~mm}$ to $961 \mathrm{~mm}$. Therefore, the year water balance (rainfall $m i$ nus ETP) ranges from positive values in the hilly station of Monte Rufeno, to negative ones in all the others, with a negative peak $(-473 \mathrm{~mm})$ in Rome and a very high variation coefficient $(\mathrm{CV}=92 \%)$. In contrast, the summer water deficit is more spread and homogeneous throughout Italy, ranging from -265 $\mathrm{mm}$ in the hilly station (Monte Rufeno) to $-411 \mathrm{~mm}$ in Rome, with a lower variation coefficient $(\mathrm{CV}=14 \%)$.

Therefore, the Italian vegetation grows from June to August under severe water limitation, also in the higher elevation sites, with rainfalls that fulfill less than half of the evapotranspirative demand (from $40 \%$ to $20 \%$ ).

The climatic data of Naples (Fig. 3) indicate a strong correlation between the monthly water

Table 2. Meteorological parameters of some Italian stations (mean values of 200-2004).

\begin{tabular}{|c|c|c|c|c|c|c|c|c|}
\hline \multirow{3}{*}{ Location } & \multirow{3}{*}{$\begin{array}{l}\text { Latitude } \\
\quad\left({ }^{\circ} \mathrm{N}\right)\end{array}$} & \multirow{3}{*}{$\begin{array}{l}\text { Elevation } \\
\text { (m a.s.l.) }\end{array}$} & \multicolumn{4}{|c|}{ Year conditions } & \multicolumn{2}{|c|}{$\begin{array}{l}\text { Summer conditions } \\
\text { (Jun-Aug) }\end{array}$} \\
\hline & & & $\begin{array}{c}\text { Mean } \\
\text { Temperature }\end{array}$ & Rain & ETo & $\begin{array}{l}\text { Rain- } \\
\text { ETo }\end{array}$ & $\begin{array}{l}\text { Rain- } \\
\text { ETo }\end{array}$ & $\begin{array}{l}\text { Rain: } \\
\text { ETo }\end{array}$ \\
\hline & & & $\left({ }^{\circ} \mathrm{C}\right)$ & & (mm year-1) & & $(\mathrm{mm})$ & $(\%)$ \\
\hline Grugliasco & $45^{\circ} 04^{\prime}$ & 293 & 12.0 & 746 & 1014 & -268 & -325 & 33 \\
\hline Sala Baganza & $44^{\circ} 43^{\prime}$ & 200 & 12.9 & 856 & 881 & -25 & -265 & 38 \\
\hline Colognole & $42^{\circ} 52^{\prime}$ & 30 & 16.3 & 669 & 888 & -219 & -307 & 21 \\
\hline M.te Rufeno & $42^{\circ} 49^{\prime}$ & 675 & 12.0 & 961 & 913 & +47 & -304 & 30 \\
\hline Roma & $41^{\circ} 44^{\prime}$ & 18 & 21.4 & 575 & 1047 & -473 & -411 & 13 \\
\hline Portici & $40^{\circ} 49^{\prime}$ & 70 & 21.8 & 621 & 841 & -221 & -306 & 18 \\
\hline Bellizzi & $40^{\circ} 12^{\prime}$ & 30 & 22.3 & 831 & 1003 & -138 & -352 & 18 \\
\hline
\end{tabular}


deficit and the monthly cumulated ozone concentrations (Fig. 4).

Several experiments demonstrated that water shortage reduces stomatal conductance and limits $\mathrm{O}_{3}$ uptake and damage (Fagnano and Merola, 2007; Bou Jaoudé et al., 2008b; Maggio and Fagnano, 2008).

Italian climate is also characterized by $5-6$ months of water surplus (rainfall $>$ evapotranspiration), that could reduce oxygen availability for the roots in clay soils (Fagnano and Maggio, 2008). This was found to reduce chlorophyll content (Ashraf and Mehmood, 1990) and $\mathrm{g}_{\text {sto }}$ from 1 to $0.1 \mathrm{~mol} \mathrm{H}_{2} \mathrm{O} \mathrm{m}^{-2} \mathrm{~s}^{-1}$ (Issarakraisila et al., 2007) in Brassica species. Therefore also waterlogging from October to March may reduce ozone uptake by modifying crop responses to this pollutant in environments, such as the Mediterranean areas, which have high ozone levels also during autumn and spring .

\section{Soil-water quality}

Another environmental problem of Mediterranean areas is the salinization of both soils and watertable due to saltwater intrusions and inadequate irrigation management. An increase of saltwater intrusion is predicted in the future because of increasingly greater water consumption for irrigation and potable uses, coupled with a decreased rain water infiltration. This scenario may be worsened by further modifications of

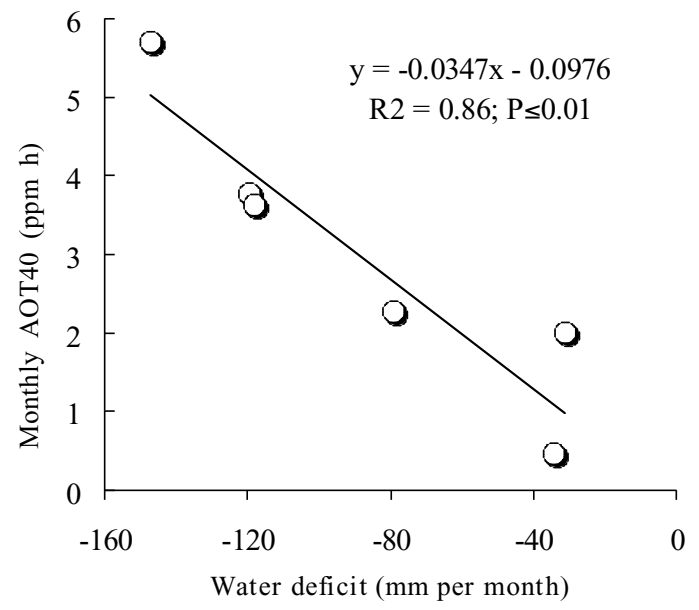

Figure 4. Correlation between monthly AOT40 and water deficit. the rainfall patterns that are likely to occur in Mediterranean areas according to current climate change predictions (Monteleone, 2006).

Some estimates report that half of irrigated land shows more or less serious problems of salinization (about $1000 \mathrm{M}$ ha) and that salinization of water tables and soils affects $2 \%$ of the total cultivated land (equal to 16 million hectares) in the Mediterranean Basin (Fagnano and Quaglietta-Chiarandà, 2004), mainly concentrated in Egypt, Algeria and Turkey (Hamdy, 2002).

In Italy, the progressive salinization of coastal plains is reported in the Po Valley (Giardini, pers. comm.), Southern Puglia and Sicily, but this may be an underestimate of the actual phenomenon because there is not a systematic monitoring of deep waters (APAT, 2002). Some studies estimated problems of salification in about 450.000 ha in Italian cropland and reported the occurrence of saline springs in the Campania region (ECe from 3.9 to $11.9 \mathrm{dS}$ $\mathrm{m}^{-1}$, Postiglione, 2002), in Puglia (ECe from 1.1 to $4.2 \mathrm{dS} \mathrm{m}^{-1}$, Caliandro et al., 1997) ed in Sicily (ECe until to $6 \mathrm{dS} \mathrm{m}^{-1}$, Fierotti et al., 1999).

Salinity of irrigation water is a well known problem because it represents a strong environmental emergency with heavy social and economic impacts in many countries, where even non-conventional waters, such as salt water, drainage water or waste water are used for irrigation purpose (Bouwer, 2000; Pereira et al., 2002).

For instance, in some Mediterranean areas, such as North Africa, characterized by high evapotranspirative demand, low leaching rainfalls and frequent seawater intrusions in watertables, saline waters $\left(\mathrm{ECe}>1 \mathrm{dS} \mathrm{m}^{-1}\right)$ are normally used for irrigation (Katerji, 2002).

The effects of soil salification on the physiology of most crops in relation to ozone damages have also been documented (Maggio et al., 2007; Maggio and Fagnano, 2008). Salinization reduces the soil water potential and will cause water stress. Crops respond to such water limitation by decreasing leaf gas-exchange, to counteract irreversible water loss and tissue dehydration. In several experiments, $\mathrm{g}_{\text {sto }}$ has been reduced by saline stress from 15 to $72 \%$ depending on species considered, the soil texture and the stress magnitude (De Pascale et al., 1995, 2003; van Hoorn et al., 1993; Katerji et al., 1996, 1997, 1998; Maggio et al., 2005). 
The promoting effect of the aforementioned environmental constraints on the accumulation of antioxidants should also be considered, since these stress-metabolites may further increase the ozone detoxification capacity of Mediterranean crops (Nali et al., 2004; Maggio and Fagnano, 2008).

\section{Conclusions}

The environmental conditions of Italian cropping systems are characterized by several stressors that reduce gas exchange and yield.

High ozone pollution levels in rural areas, water deficit during spring-summer periods and irrigation with saline water are known to be the main limiting factors for crop growth and future scenarios predict further environmental constraints for Italian cropping systems.

Nevertheless, all these stressors may reduce stomatal conductance and thus plant ozone uptake. Therefore crop responses to this harmful pollutant could be strongly modified by other environmental stress responses that typically overlap to critical periods of plant exposure to ozone.

\section{Acknowledgements}

CONECOFOR of Italian Ministry for Agriculture and Forests, Dept. of Plant Biology of Rome University "La Sapienza" and Dept. of Agronomy, Forest and Land Management of Turin University are gratefully acknowledged for supplying the data which have been used for meteorological analyses.

\section{References}

APAT 2002. Annuario dei dati ambientali. Stato dell'ambiente, 8, p. 80 .

Ashraf M., Mehmood S. 1990. Effects of waterlogging on growth and some physiological parameters of four Brassica species. Plant Soil, 121:203-209.

Bou Jaoudé M., Katerji N., Mastrorilli M., Rana G. 2008a. Analysis of the effect of ozone on soybean in the Mediterranean region I. The consequences on crop-water status. European Journal of Agronomy, in press.

Bou Jaoudé M., Katerji N., Mastrorilli M., Rana G. 2008 b. Analysis of the effect of ozone on soybean in the Mediterranean region II. The consequences on growth, yield and water use efficiency. European Journal of Agronomy, in press.
Bouwer H. 2000. Integrated water management: emerging issues and challenges. Agricultural Water Management, 45:217-228.

Caliandro A., Rubino P., Lonigro A. 1997. Monitoraggio di acque di falda a diverso contenuto in sale. Agricoltura Ricerca, 171:13-16.

Darrall M.N. 1989. The effect of air pollutants on physiological processes in plants. Plant Cell Environment, 12:1-30.

De Pascale S., Barbieri G., Sifola M.I., Ruggiero C. 1995. Gas exchanges, water relations and growth of eggplant (Solanum melongena L.) as affected by salinity of irrigation water. Acta Horticulturae, 412:388-395.

De Pascale S., Maggio A., Barbieri G., Ruggiero C. 2003. Physiological response of pepper (Capsicum annuum L.) to salinity and drought. J. American Soc. Horticultural Sciences, 128:48-54.

Fagnano M. 1995. Tropospheric ozone concentration in Portici (Naples) in relation to meteorological parameter. Agricoltura Mediterranea, S.V.:390-394.

Fagnano M., Quaglietta Chiarandà F. 2004. Relazioni tra qualità dell'ambiente e produzione agricola. Rivista di Agronomia, 38:33-84.

Fagnano M., Merola G. 2007. Ozone and water stress: effects on the behavior of two white clover biotypes. Italian Journal of Agronomy, 2:3-12.

Fagnano M., Merola G., Cefariello R. 2007. Risposta dell'erba medica all'inquinamento da ozono con livelli crescenti di stress salino. Proceed. XXXVII Cong. SIA, 13-14 Sept. 2007, Catania, 331-332.

Fagnano M., Maggio A., Fumagalli I. 2008. Crops responses to ozone in Italy. Environmental Pollution., in press.

Ferretti M. Fagnano M., Amoriello T., Badiani M., Ballarin-Denti A., Buffoni A., Bussotti F., Castagna A., Cieslik S., Costantini A., De Marco A., Gerosa G., Lorenzini G., Manes F., Merola G., Nali C., Paoletti E., Petriccione B., Racalbuto S., Rana G., Ranieri A., Tagliaferri A., Vialetto G., Vitale M. 2007. Measuring, modelling and testing ozone exposure, flux and effects on vegetation in southern European conditions What does not work? A review from Italy. Environmental Pollution, 146:648-658.

Fierotti G., Dazzi C., Tusa D. 1999. Riflessi dell'irrigazione con acque saline sulla qualità dei suoli. In: Tarantino E., Perniola M. (eds): Atti Conv. POM "Le acque salmastre come risorsa idrica: limiti e prospettive", 5 maggio 1999, 7-22.

Forlani A., Merola G., Fagnano M. 2005. Ozone effects on vegetation in three different localities of Campania region. Fresenius Environmental Bulletin, 14:478-483.

Fuhrer J., Skarby L., Ashmore M.R. 1997. Critical levels for ozone effects on vegetation in Europe. Environmental Pollution, 97:91-106.

Grulke N.E., Paoletti E., Heat R.L. 2007. Comparison of calculated and measured foliar $\mathrm{O} 3$ flux in crop and forest species. Environmental Pollution, 146:640-647

Guderian R. 1985. Air pollution by photochemical oxidants. Formation, transport, control and effects on 
plants. Ecologial Studies, Vol. 52. Springer Verlag, Berlin.

Hamdy A. 2002. Saline irrigation management for a sustainable use. In: Mediterranean crop responses to water and soil salinity: ecophysiological and agronomic analyses. CHIEAM, Bari, Options méditerranées, B 36:185-230.

Hayes F., Mills G., Harmens H., Norris D. 2007. Evidence of Widespread Ozone Damage to Vegetation in Europe (1990-2006). Centre for Ecology and Hydrology, Bangor (UK), pp. 60.

Hargreaves G.L., Hargreaves G.H., Riley J.P. 1985. Agricultural benefits for Senegal river basin. J. Irrigation and Drainage Engineering, 111:113-124.

Heck W.W., Taylor O.C., Adams R., Bingham G., Miller J., Preston E., Weinstein L. 1982. Assessment of crop loss from ozone. J. Air Pollution Control Association, 32:353-361.

Iqbal M., Abdin M.Z., Yunus M., Agrawal M. 1996. Resistance mechanism in plants against air pollution. In: Yunus M., Iqbal M. (eds.): Plant response to air pollution, 195-240. J. Wiley \& Sons, Chichester (UK)

Issarakraisila M., Ma Q,. Turner D.W. 2007. Photosynthetic and growth responses of juvenile Chinese kale (Brassica oleracea var. alboglabra) and Caisin (Brassica rapa subsp. parachinensis) to waterlogging and water deficit. Scientia Horticulturae, 111:107-113.

Katerji N. 2002. Productivity analysis of crop grown in saline environment: presentation of the major research lines. In: Mediterranean crop responses to water and soil salinity: eco-physiological and agronomic analyses. CHIEAM Bari, Options Méditerranées B 36:231-249.

Katerji N., van Hoorn J.W., Hamdy A., Karam F., Mastrorilli M. 1996. Effect of salinity on water stress, growth and yield of maize and sunflower. Agricultural Water Management, 30:237-249.

Katerji N., van Hoorn J.W., Hamdy A., Mastrorilli M., Mou Karzel E. 1997. Osmotic adjustment of sugar beets in response to soil salinity and its influence on stomatal conductance, growth and yield. Agricultural Water Management, 34:57-69

Katerji N., van Hoorn J.W., Hamdy A., Mastrorilli M. 1998. Response of tomatoes, a crop of indeterminate growth to soil salinity. Agricultural Water Management, 38:59-68.

Lorenzini G. 1999. Le piante e l'inquinamento dell'aria, Edagricole, Bologna (I), 335 pp.

Maggio A., De Pascale S., Fagnano M., Barbieri G. 2007. Can salt stress-induced physiological responses protect tomato crops from ozone damages in Mediterranean environments? European Journal of Agronomy, 26:454-461.

Maggio A., Raimondi G., Martino A., De Pascale S. 2005. Microtom: una pianta modello per studiare la biologia funzionale dello stress salino in pomodoro. In: Proceed. XXXVI SIA Congress. 20-22 September 2005, Foggia (I), 182-182.
Maggio A., Fagnano M. 2008. Ozone Damages to Mediterranean Crops: Physiological Responses. Italian Journal of Agronomy, this issue.

Manes F., Giannini M.A., Carogna F., De Bonfils A., Postiglione L., Fagnano M., Merola G., Forlani A., Piccolo R., Fumagalli I., Belgiovine N., Mignanego L., Vialetto G., Racalbuto S. 2002. Livelli critici di ozono ed effetti sulle piante in Italia. Energia, Ambiente, Innovazione, 48, 5:55-65.

Merola G., Fagnano M. 2006. Interaction between Stress typical of the Mediterranean Area: Ozone damages and Water Stress on Trifolium repens and Lolium perenne. In: Wieser G., Tausz M. (eds.): Critical levels of ozone: further applying and developing the flux-based concept, 289-292. BFW, Vienna.

Monteleone M. 2006. Problematiche della salinità nelle acque irrigue meridionali. Italian J. Agronomy, 1:129-202.

Musselman R.C., Minnick T.J. 2000. Nocturnal stomatal conductance and ambient air quality standards for ozone. Atmospheric Environment, 34:719-733.

Nali C., Pucciarello C., Lorenzini G. 2002. Ozone distribution in central Italy and its effect on crop productivity. Agriculture Ecosystem Environment, 90:277-289.

Nali C., Paoletti E., Marabottini R., Della Rocca G., Lorenzini G., Paolacci A.R., Ciaffi M., Badiani M. 2004. Ecophysiological and biochemical strategies of response to ozone in Mediterranean evergreen broadleaf species. Atmospheric Environment, 38: 2247-2257.

Paoletti E. 2005. Ozone slows stomatal response to light and leaf wounding in a Mediterranean evergreen broadleaf, Arbutus unedo. Environmental Pollution, 134:439-445.

Pereira L.S., Oweis T., Zairi A. 2002. Irrigation management under water scarcity. Agricultural Water Management, 57:175-206.

Postiglione L. 2002. Soil salinization in the Mediterranean: soils, processes and implications. In: Geeson N.A., Brandt C.J., Thornes J.B. (eds.): Mediterranean desertification: a mosaic of processes and responses, 163-173. J. Wiley \& Sons, Chichester (UK).

Schenone G., Fumagalli I., Mignanego L., Montanaro F., Soldatini G.F. 1994. Effect of ambient air pollution in open-top chambers on bean (Phaseolus vulgaris L.). II. Effects on photosynthesis and stomatal conductance. New Phytologist, 126:309-315.

Sitch S., Cox P.M., Collins W.J., Huntingford C. 2007. Indirect radiative forcing of climate change through ozone effects on the land-carbon sink. Nature, 448:971-794.

Vecchi R., Valli G. 1999. Ozone assessment in the southern part of the Alps. Atmospheric Environment, 33:97-109.

van Hoorn J.W., Katerji N., Hamdy A., Mastrorilli M. 1993. Effect of saline water on soil salinity and on water stress, growth and yield on wheat and potatoes. Agricultural Water Management, 23:247-265. 